\title{
Toxicity and chemistry of the sea-surface microlayer in the North Sea using a cryopreserved larval bioassay
}

\author{
I. R. B. McFadzen, J. J. Cleary \\ Natural Environment Research Council, Plymouth Marine Laboratory, Prospect Place, West Hoe, Plymouth PL1 3DH, \\ United Kingdom
}

\begin{abstract}
Samples of sea-surface microlayer (SMIC) and subsurface bulkwater were collected along a pollution gradient in the German Bight region of the North Sea in March 1990. Toxicity was assessed using cryopreserved veliger larvae of the Pacific oyster Crassostrea gigas L. and the Manila clam Tapes philippinarum Adams \& Reeve. Water samples were analysed for copper, lead and organotins. The results indicate that toxicity and chemical concentrations are greater in the microlayer than in the subsurface waters and decline with increased distance offshore.
\end{abstract}

KEY WORDS: Microlayer - Toxicity Cryopreserved Larvae - Oyster Clam

\section{INTRODUCTION}

Historically, several genera of marine invertebrates have been used to monitor the integrated biological effects of contaminants (Stebbing 1985). In particular, the embryonic stages of the Pacific oyster Crassostrea gigas L. have been used to assess the effects of contaminants on development to the prodissoconch (D-shell) larva (Woelke 1972, Thain 1991). Recently, larval stages of the oyster and the Manila clam Tapes philippinarum Adams \& Reeve have been successfully cryopreserved and deployed in environmental impact assessment (McFadzen 1992).

Cryopreservation techniques eliminate reproductive seasonality, minimise genetic heterogeneity between tests and maintain viable veliger larvae over indefinite time periods. The benefits of this technique have been demonstrated in commercial hatcheries (Utting \& McFadzen 1990).

It is particularly appropriate to use larval stages to determine microlayer toxicity since many species of fish and invertebrates have surface dwelling larval stages which may be exposed to the enriched concentrations of potentially toxic chemicals which occur in the microlayer at the air-sea interface (Kocan et al. 1987, von Westernhagen et al. 1987). Potential toxicants such as copper $(\mathrm{Cu})$, lead $(\mathrm{Pb})$ and tributyltin (TBT) can be highly enriched in the surface microlayer by as much as 1000 times bulkwater values (Pattenden et al. 1981). Even greater enhancements can occur with organic compounds such as polyaromatic hydrocarbons (PAHs) and polychlorinated biphenyls (PCBs) (Baier et al. 1974, Brockman et al. 1976, Cross et al. 1987, Hardy et al. 1987).

The objectives of this study were to (1) evaluate the use of cryopreserved larvae as a means of determining microlayer toxicity and (2) determine the concentrations of chemical contaminants in the microlayer and their relation with toxicity.

\section{METHODS}

Sample collection. Samples were collected as part of the ICES/IOC Biological Effects of Contaminants Workshop (Stebbing \& Dethlefsen 1992) during a cruise of the RV 'Valdivia' (University of Hamburg) in March 1990 at 4 stations in the German Bight area of 


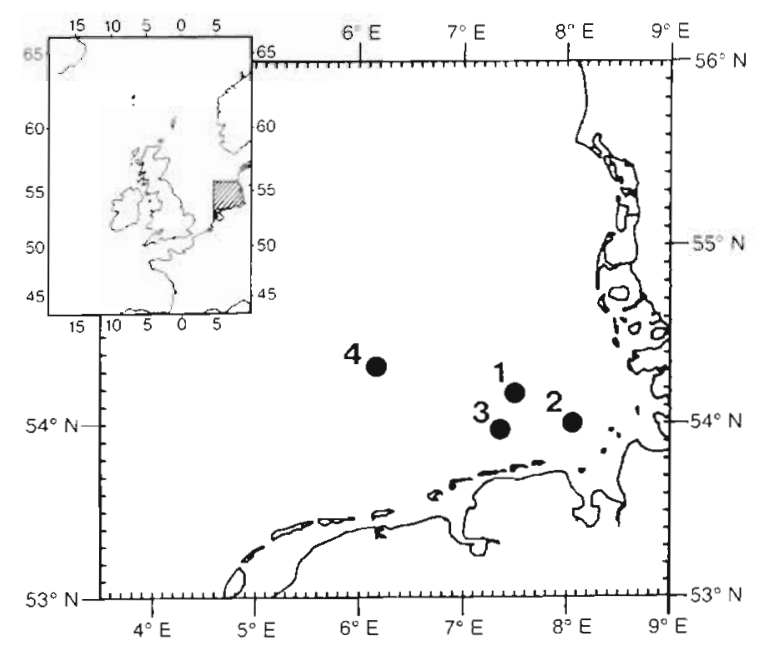

Fig. 1. Sampling station locations in the German Bight

the North Sea (Fig. 1). To avoid local sample contamination from the ship, water samples were taken at least $200 \mathrm{~m}$ upwind from the ship from a small inflatable boat (Table 1). Methods used to collect microlayer samples (280 to $300 \mu \mathrm{m}$ ) and subsurface waters have been described previously (Cleary \& Stebbing 1987). Microlayer samples (2 l) were collected by the Garrett screen method (Garrett 1965), using a stainless steel screen for organotin sampling and a nylon screen for metals.

Toxicity assessment. Cryopreservation and larval storage: Recently developed proprietary freezing and thawing techniques were used. The methodologies for these are described in PCT Published Patent Application No. WO 91/91636, published 21 February 1991. Larvae of each species were cryopreserved en masse in a single freezing protocol in multiple $5 \mathrm{ml}$ plastic straws and stored under liquid nitrogen $\left(-196^{\circ} \mathrm{C}\right)$ for $3 \mathrm{~d}$. Frozen straws of larvae were transferred to precooled $\left(-150^{\circ} \mathrm{C}\right)$ dry shippers for transportation to the Workshop (McFadzen 1992). Larvae were maintained at temperatures below $-150^{\circ} \mathrm{C}$ for between 5 and $10 \mathrm{~d}$ until thawed for use in the bioassay aboard the RV 'Valdivia' Oyster larvae were cryopreserved $24 \mathrm{~h}$ post-fertilisation (while lecithotrophic) and clam larvae $48 \mathrm{~h}$ post-fertilisation, after $24 \mathrm{~h}$ of exogenous feeding

Toxicity test: To reduce any possible interstraw variability, 3 straws of each species were thawed individually (to a temperature of 20 to $22^{\circ} \mathrm{C}$ ) then pooled in 'clean' reference seawater (Burnhamon-Crouch winter water). Larval viability and numbers recovered from straws were assessed 30 min post-thaw (Table 2) before exposure to the sample.
Table 1. Station locations, sample date and wind conditions

\begin{tabular}{|ccccc|}
\hline Stn & Date & $\begin{array}{c}\text { Latitude } \\
(\mathrm{N})\end{array}$ & $\begin{array}{c}\text { Longitude } \\
(\mathrm{E})\end{array}$ & $\begin{array}{c}\text { Wind state } \\
\text { (Beaufort) }\end{array}$ \\
\hline $1^{\circ}$ & $16 \operatorname{Mar} 90$ & $54^{\circ} 13^{\prime}$ & $07^{\circ} 57^{\prime}$ & $3-4$ \\
2 & $17 \operatorname{Mar} 90$ & $54^{\circ} 02^{\prime}$ & $08^{\circ} 03^{\prime}$ & $2-5$ \\
3 & $17 \operatorname{Mar} 90$ & $54^{\circ} 02^{\prime}$ & $07^{\circ} 50^{\prime}$ & $0-1$ \\
4 & $18 \operatorname{Mar} 90$ & $54^{\circ} 25^{\prime}$ & $06^{\circ} 14^{\prime}$ & $3-4$ \\
& & & \\
\end{tabular}

Table 2. Larval viability and number recovered from each straw assessed 30 min post-thaw. Mean $\pm S D$ based upon 3 straws per batch. Initial length measurements are given (mean $\pm \mathrm{SD}$ ) for each species 30 min post-thaw, $\mathrm{n}=50$. Oyster lärvae were cryopreserved $24 \mathrm{~h}$ post-fertilisation and clam larvae $48 \mathrm{~h}$ post-fertilisation

\begin{tabular}{|cccc|}
\hline & $\begin{array}{c}\% \text { Viability } \\
\text { per straw }\end{array}$ & $\begin{array}{c}\text { No. recovered } \\
\text { per straw }\end{array}$ & $\begin{array}{c}\text { Initial length } \\
(\mu \mathrm{m})\end{array}$ \\
\hline $\begin{array}{c}\text { Batch 1 } \\
\text { Oyster }\end{array}$ & $97.1 \pm 1.0$ & $1845 \pm 13.2$ & $71.0 \pm 2.04$ \\
Clam & $97.3 \pm 1.53$ & $1036 \pm 18.7$ & $86.44 \pm 2.88$ \\
Batch 2 & & & \\
Oyster & $97.0 \pm 1.73$ & $1860 \pm 20.1$ & $70.11 \pm 2.34$ \\
Clam & $96.67 \pm 2.08$ & $1240 \pm 23.7$ & $85.65 \pm 3.01$ \\
\hline
\end{tabular}

Approximately 300 larvae were concentrated into a minimum volume of reference seawater on a $45 \mu \mathrm{m}$ nytex mesh. Larvae were then rinsed with a small volume $(<1 \mathrm{ml})$ of test water before decanting into duplicate (subsample) $30 \mathrm{ml}$ glass vials (10 larvae $\mathrm{ml}^{-1}$ ) containing the sample seawater. All vials of sample water were spiked with $100 \mu \mathrm{l}$ of ca 100 to 200 cells $\mu \mathrm{l}^{-1}$ Isochrysis galbana (to provide a minimum algal ration for the exposure period (Utting \& Spencer 1991). Sample water was then equilibrated to the incubation temperature $\left(20^{\circ} \mathrm{C}\right)$ prior to the addition of the larvae. All samples were maintained under static conditions and stored at $20^{\circ} \mathrm{C}$ for $48 \mathrm{~h}$. Each vial was then treated with $4 \%$ buffered formalin to preserve the larvae for subsequent analysis (McFadzen 1992)

Table 3. Concentrations (ng $)^{-1}$ ) of metal in microlayer (SMIC) and subsurface bulkwater (B) samples

\begin{tabular}{|rrrrrrrrr|}
\hline \multirow{2}{*}{ Stn } & \multicolumn{2}{c}{ Cu } & \multicolumn{2}{c}{ Pb } & \multicolumn{2}{c}{ Organotin } & \multicolumn{2}{c|}{ TBT } \\
& SMIC & B & \multicolumn{1}{c}{ SMIC } & B & SMIC & B & SMIC & B \\
\hline 1 & 4650 & 1210 & 2073 & 1101 & 51.3 & 3.1 & 8.1 & 1.4 \\
2 & 1960 & 440 & 1127 & 335 & 18.7 & 4.0 & 4.9 & 2.4 \\
3 & 1405 & 740 & 1605 & 510 & 27.3 & 1.8 & 4.7 & 0.7 \\
4 & 2950 & 340 & 770 & 495 & 9.6 & 3.2 & 3.2 & 0.3 \\
\hline
\end{tabular}


Microscopic examination of larvae was conducted at random with survival assessed as the number of viable larvae observed in the first 50 larvae encountered. Initial length measurements of viable larvae were made at the Workshop, using a graticule eye piece fitted to a Leitz compound microscope (Table 2). Subsequent semi-automated analysis of larvae was carried out using a Kontron IPS image analyser, linked to a Reichert Polyvar microscope, measuring maximum length parallel to the valve hinge.

Chemical analyses. Organotins: A 21 water sample was acidified with $50 \mathrm{ml}$ of glacial acetic acid and extracted with $25 \mathrm{ml}$ of toluene by vigorously shaking on an orbital shaker for $15 \mathrm{~min}$. The sample was transferred to a separatory funnel and the lower aqueous layer run off. The water was further separated by centrifugation and the toluene extract sealed and frozen until analysis. Where necessary the extracts were preconcentrated prior to analysis. Aliquots were treated with $1 \mathrm{M} \mathrm{NaOH}$ and reanalysed to determine tributyltin (Cleary 1991).

Trace metals: Trace metals were collected from the seawater samples by solvent extraction (Danielsson et al. 1982). Metal carbamate complexes were extracted from seawater (buffered to $\mathrm{pH} 5.0$ ) with ammonium pyrrollidine dithiocarbamate (APDC) and diethylammonium diethyldithiocarbamate (DDDC) into 1, 1,2trichloro-1,2,2-trifluoroethane (Freon TF) and backextracted into $0.3 \mathrm{M} \mathrm{HNO}_{3}$ prior to analysis by graphite furnace atomic absorption.

\section{RESULTS}

\section{Chemical concentrations}

Microlayer concentrations of $\mathrm{Cu}, \mathrm{Pb}, \mathrm{TBT}$ and organotins were greater than in subsurface waters at all sampling stations (Table 3). Maximum microlayer concentrations occurred at Stn 1 (Helgoland) and generally declined to a minimum at $\operatorname{Stn} 4$, the most offshore site (Fig. 2). Organotin and TBT showed greater enhancement than $\mathrm{Cu}$ and $\mathrm{Pb}$. Mean enhancement ratios, i.e. concentration in $\mathrm{SMIC/concentration} \mathrm{at}$ $0.5 \mathrm{~m}$, were 9.8 (organotins), 6.3 (TBT), $5.0(\mathrm{Cu})$ and 2.3 (Pb) (Table 3).

\section{Larval toxicity}

Species difference. The survival of clam larvae exposed to microlayer and bulkwater increased along the transect from the coastal water at Stn 1 (Helgoland) to Stn 4 about $280 \mathrm{~km}$ from the mouth of the River Elbe. Larvae exposed to the surface microlayer
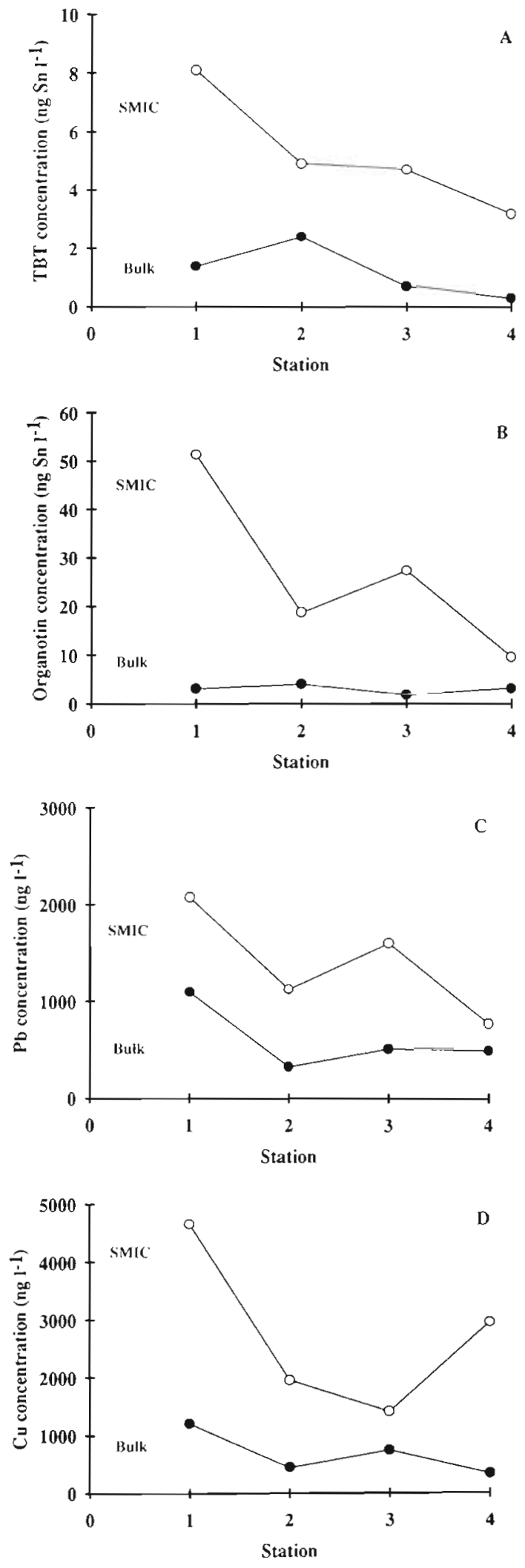

Fig. 2. Concentrations of (A) tributyltin (TBT), (B) organotin, (C) lead (Pb) and (D) copper (Cu) in the sea-surface microlayer (SMIC) and subsurface bulkwater (Bulk) 

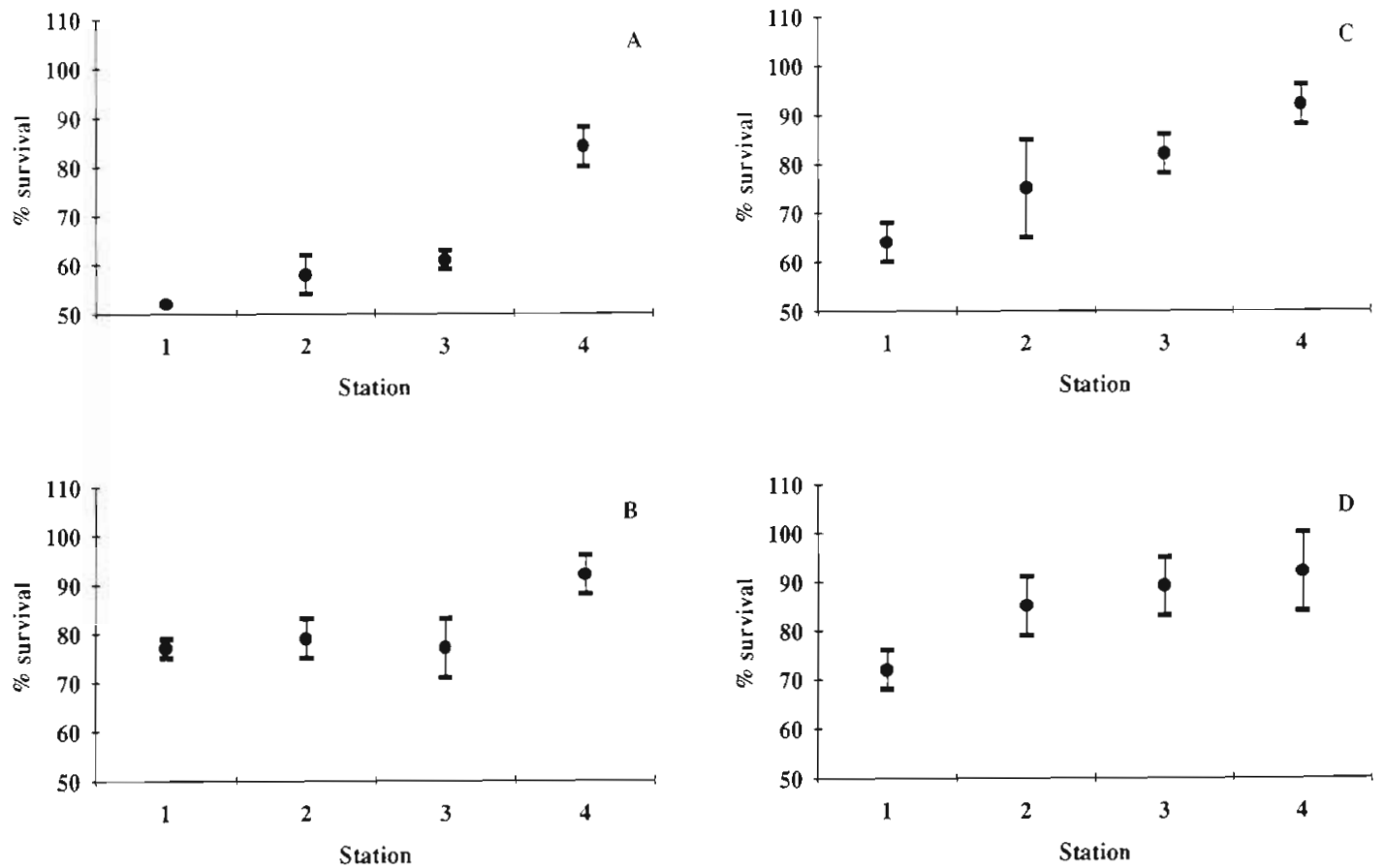

Fig. 3. Percentage survival of larvae following $48 \mathrm{~h}$ exposure (mean \pm 2 SE). Mean based on 2 replicate subsamples. (A) Tapes philippinarum (age 4.8 to $96 \mathrm{~h}$ ); microlayer. (B) T. philippinarum; $0.5 \mathrm{~m}$ subsurface water. (C) Crassostrea gigas (age 24 to $72 \mathrm{~h}$ ); microlayer (D) C. gigas; $0.5 \mathrm{~m}$ subsurface water
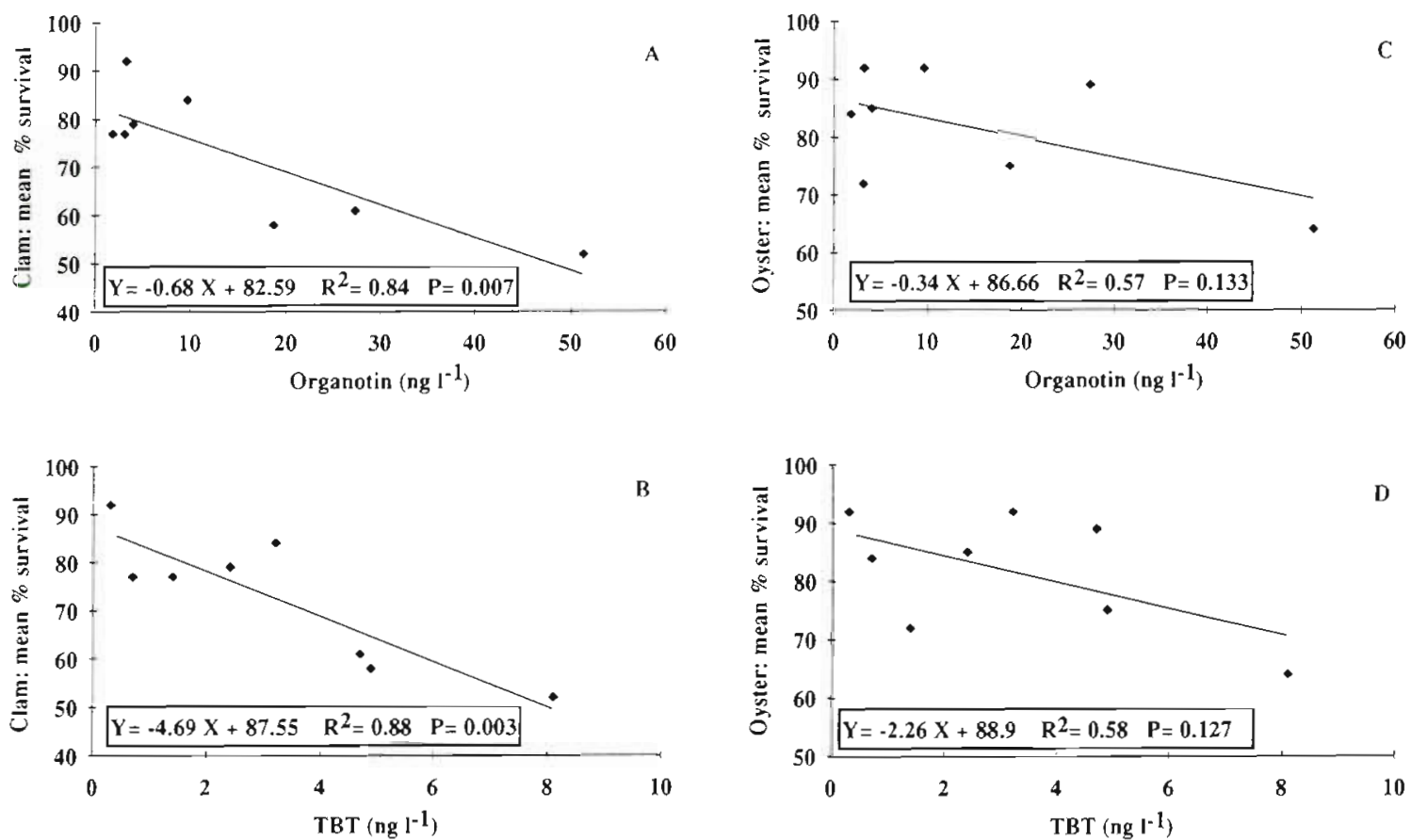

Fig. 4. Relation of the percentage survival of larvae with increasing contaminant concentration for combined microlayer and bulkwater samples from all stations. (A) Tapes philippinarum; organotin. (B) T philippinarum; tributyltin. (C) Crassostrea gigas; organotin. (D) C. gigasi tributyltin. Note that all units refer to ng Sn $\mathrm{I}^{-1}$ 
showed significantly greater toxicity than those exposed to bulkwater (Fig. 3A, B). Oyster larvae also showed the greatest toxicity at the inshore Stn 1 in both the microlayer and bulkwater, and then declined with distance from the coast (Fig. 3C, D). No differences in survival between species were observed in the bulkwater (Fig. 3B, D; however older clam larvae had significantly higher mortalities than oyster larvae exposed to the microlayer at all transect stations (Fig. $3 \mathrm{~A}, \mathrm{C})$.

Covariance. The survival of clam larvae exposed to microlayer and bulkwater showed an inverse relationship to the organotin and TBT concentrations (Fig. 4A, $\mathrm{B})$. A similar covariance was seen with $\mathrm{Cu}$ and $\mathrm{Pb}$ (Fig. 5A, B). Oyster larvae covariance was not so evident and no correlation was observed with organotin and TBT (Fig. 4C, D), although $\mathrm{Cu}$ and $\mathrm{Pb}$ did show a positive relationship (Fig. 5C, D).

Larval growth. Clam larvae grew significantly more in the inshore Stns (1 to 3) compared to Stn 4 (Fig. 6A, B) for both SMIC and bulkwater. Larvae in the bulkwater were larger than those exposed to the SMIC at Stns 2, 3 \& 4 (Fig. 6A, B). Oysters did not show any length differences either between stations or sample types with bulkwater larvae having a greater variability in length (Fig. 6C, D).

\section{DISCUSSION}

High microlayer concentrations of metals, organotin and TBT in the sea-surface microlayer (Fig. 2) have been reported previously in near coastal waters (Hall et al. 1986, Cleary 1991) and offshore by Hardy \& Cleary (1992). Similar microlayer enrichment occurred in this study (Fig. 2), and microlayer concentrations of TBT and $\mathrm{Cu}$ were higher than water quality criteria established for marine life protection, namely the U.K.

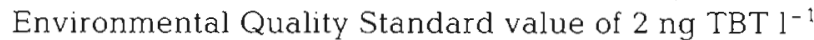
and the U.S. Environmental Protection Agency chronic water quality limit of $2.9 \mu \mathrm{g} \mathrm{Cu} \mathrm{l}^{-1}$. Copper and $\mathrm{Pb}$ concentrations in $0.5 \mathrm{~m}$ subsurface waters were in good agreement with data for $10 \mathrm{~m}$ subsurface samples taken 1 wk earlier (Cofino et al. 1992) at the same sampling stations and with other literature values (Kremling \& Hydes 1988, Sünderman \& Degens 1989).

Significant covariance was observed between larval exposure and $\mathrm{Cu}, \mathrm{Pb}$, organotin and TBT concentrations (Figs. $4 \& 5$ ). Although correlation between contaminant concentration and larval mortality does not prove cause and effect, these data suggest that there may be an environmentally significant effect attributable to TBT and copper toxicity on larval stages of marine bivalves.
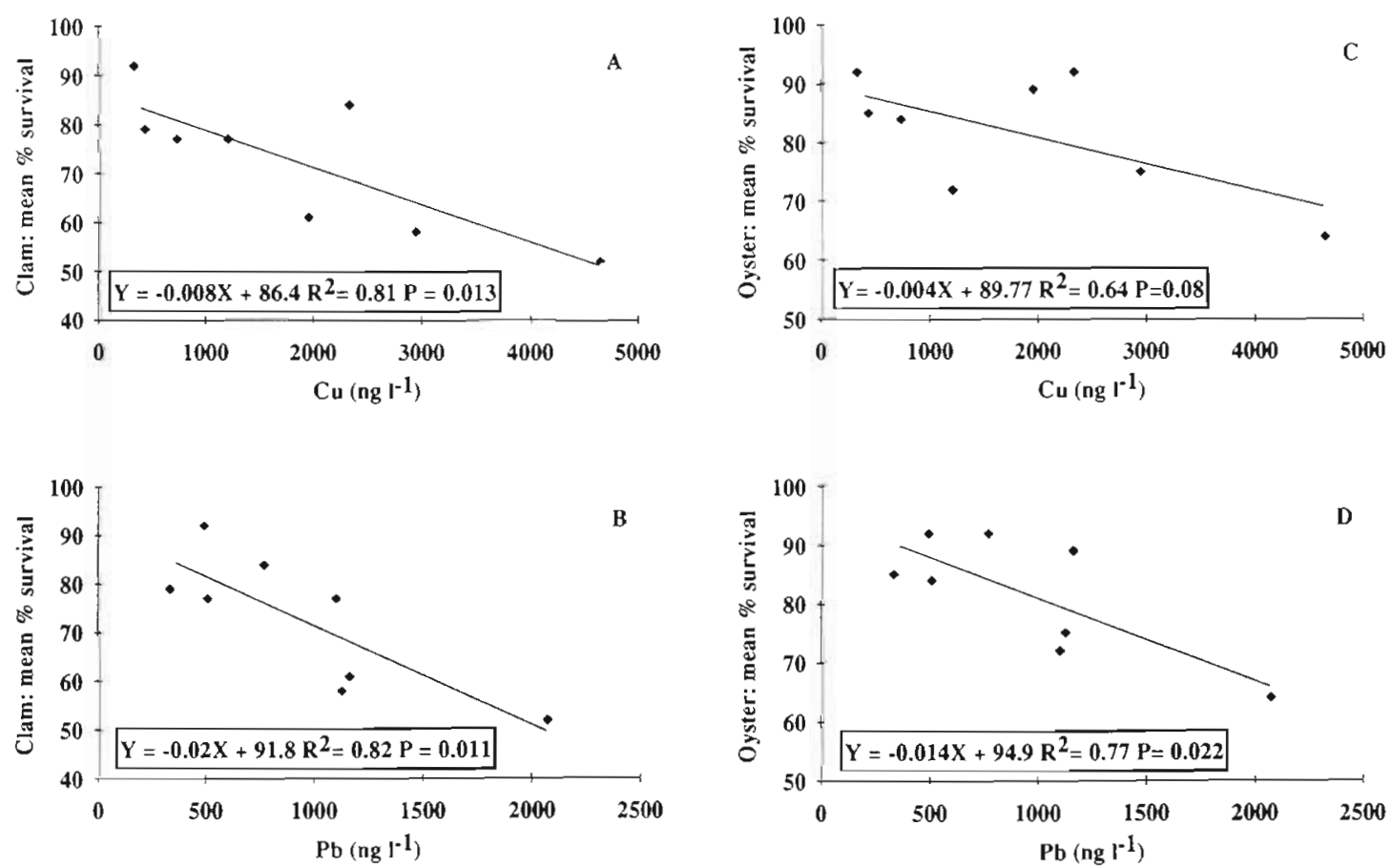

Fig. 5. Relation of the percentage survival of larvae with increasing contaminant concentration for combined microlayer and bulkwater samples from all stations. (A) Tapes philippinarum; copper. (B) T. philippinarum; lead. (C) Crassostrea gigas; copper.

(D) C. gigas; lead 

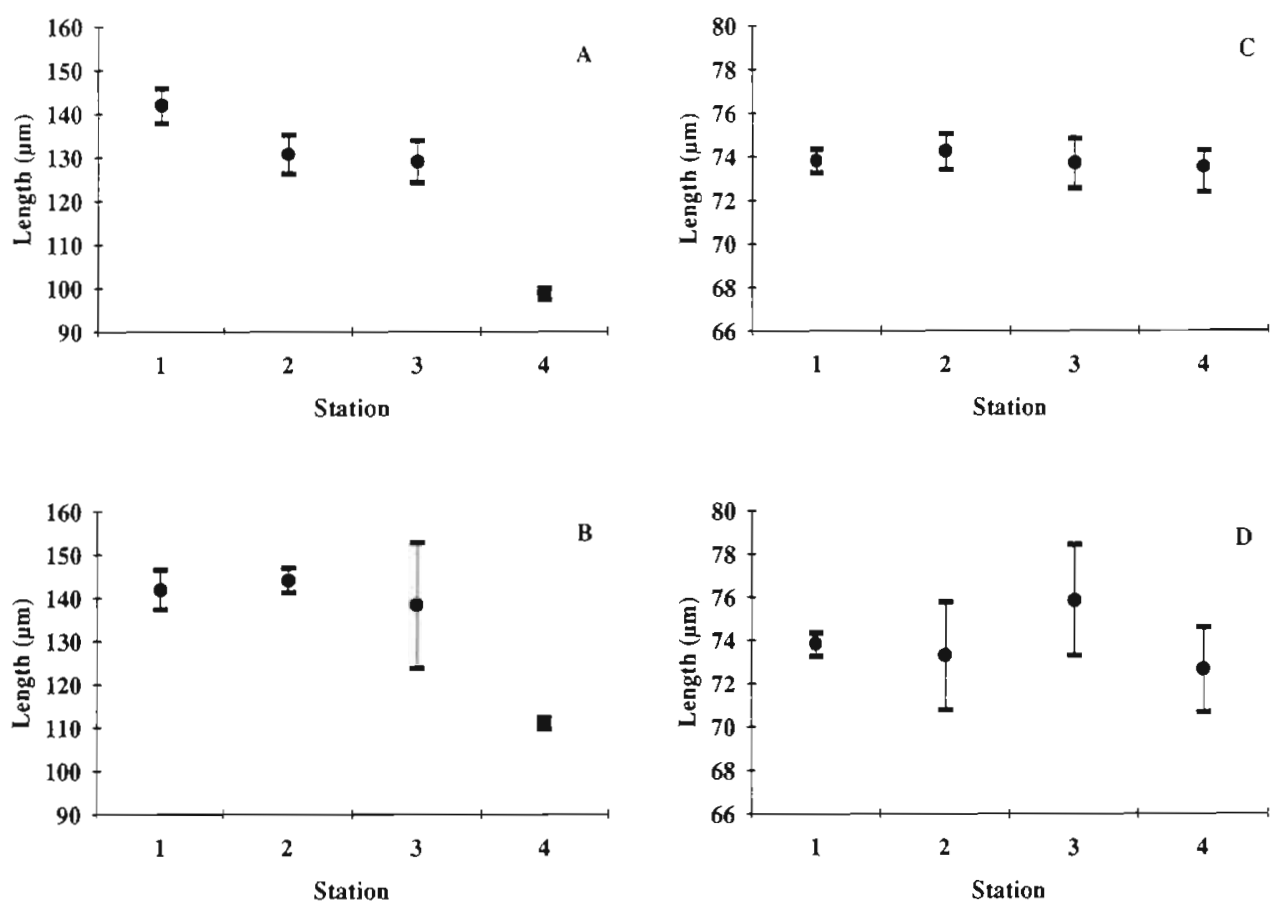

Fig. 6. Maximum shell length in microns (mean $\pm 2 \mathrm{SE}$ ). Mean based on total number of viable larvae from 2 replicate subsamples (A) Tapes philippinarum; microlayer. (B) T. philippinarum; $0.5 \mathrm{~m}$ subsurface water. (C) Crassostrea gigas; microlayer. (D) C. gigas; $0.5 \mathrm{~m}$ subsurface water

These data show significantly higher toxicity in the microlayer than in bulkwater (Fig. 3), extending from the coastal water to the southern North Sea Stn 4 . This was significantly less toxic to both species of larvae, despite their reduced levels of growth. Differential sensitivities to contaminants observed with oysters and clams (Fig. 3) could be a function of the developmental life stage employed during the exposure period (McFadzen 1992) or variation in species tolerance to xenobiotics. Growth data (Fig. 6) reflected natural levels of food organisms available to the larvae from the unfiltered samples (see McFadzen 1992).

Clearly, microlayer contamination is a potential threat to neustonic and pelagic marine organisms (Cross et al. 1987, Hardy et al. 1987, Hardy \& Cleary 1992, Karbe 1992). These data demonstrate that differential results are obtained from the same water samples when utilising different species and ages, therefore highlighting a requirement for multispecies (and life stages) testing in environmental impact assessment. It is also clear from this study that cryopreserved larvae provide a valid means of toxicity testing.

Acknowledgements. Thanks are due to Dr A. Stebbing (Plymouth Marine Laboratory) for his overall management of the Workshop and to Drs Ludwig Karbe and Jan Bening (University of Hamburg) and the crew of the RV 'Valdıvia' for logistical support. Thanks also to Drs E. Rachor and C. Pohl (Alfred Wegener Institute for Polar and Marine Research) for providing analytical facilities, and to Mary Brinsley (PML) for assistance with the field sampling. The study was funded in part by the Intergovernmental Oceanographic Commission of UNESCO, the U.K. Department of the Environment, and Cell Systems, Ltd, Cambridge. A final thank you goes to Dr I. Joint (PML) for comments during the preparation of this manuscript.

\section{LITERATURE CITED}

Baier, R. E., Goupil, D. W., Perlmutter, S., King, R. (1974). Dominant chemical composition of sea-surface films, natural slicks and foams. J. Rech. atmos. 8: 571-600

Brockmann, U. H., Kattner, G., Hentzchel, G., Wandschneider, K., Junge, H. D., Hühnerfuß, H. (1976). Natürliche Oberflächenfilme im Seegebiet vor Sylt. Mar. Biol. 36: $135-146$

Cleary, J. J. (1991). Organotin in the marine surface microlayer and subsurface waters of southwest England: relation to toxicity thresholds and the U.K. environmental quality standard. Mar. environ. Res. 32: 213-222

Cleary, J. J., Stebbing, A. R. D. (1987). Organotin in the surface microlayer and subsurface waters of southwest England. Mar. Pollut. Bull. 18: 238-246

Cofino, W., Smedes, F., de Jong, A. S., Abarnou, A., Boon, J. P., Oostingh, I., Davies, I., Klungsoyr, J., Wilhelmsen, S., Law, R., Whinnett, J. A., Schmidt, D., Wilson, S. (1992). The chemistry programme. Mar. Ecol. Prog. Ser. 91: 47-56

Cross, J., Hardy, J., Hose, J., Hershelman, G. Antrim, L., Gossett, R., Crecelius, E. (1987). Contaminant concentrations and toxicity of sea-surface microlayer near Los Angeles, California. Mar, environ. Res. 23: 307-323

Danielsson, L. D., Magnusson, B., Westerlund, S., Zhang, K. (1982). Trace metal determinations in estuarine waters by 
electrothermal atomic absorption spectrometry after extraction of dithiocarbamate complexes into Freon. Analyt. Chim. Acta 144: 183-188

Garrett, W. D. (1965). Collection of slick forming materials from the sea surface. Limnol. Oceanogr. 10: 602-605

Hall, L. W., Lenkevich, M. J., Hall, W. S., Pinkney, A. F., Bushong, S. J. (1986). Monitoring organotin concentratrons in Maryland waters of Chesapeake Bay. In: Organotin symposium proceedıngs, Vol. 4, Oceans 86. Marıne Technology Society, Washington, DC, p. 1275-1279

Hardy, J., Cleary, J. (1992). Surface microlayer contamination and toxicity in the German Bight. Mar. Ecol. Prog. Ser. 91. $203-210$

Hardy, J., Crecelius, E., Antrim, L., Broadhurst, V., Apts, C., Gurtisen, J., Fortman, T (1987). The sea-surface microlayer of Puget Sound. Part II. Concentrations of contaminants and relation to toxicity. Mar. environ. Res. 23: $251-271$

Karbe, L. (1992). Toxicity of surface microlayer, subsurface water and sediment elutriates from the German Bight: summary and conclusions. Mar. Ecol. Prog. Ser. 91: $197-201$

Kocan, R., von Westernhagen, H., Landolt, M., Furstenberg, G. (1987). Toxicity of sea-surface microlayer: effects of hexane extract on Baltic herring (Clupea harengus) and Atlantic cod (Gadus morhua) embryos. Mar. environ. Res. 23: $291-305$

Kremling, K., Hydes, D. (1988). Summer distribution of dissolved $\mathrm{Al}, \mathrm{Cd}, \mathrm{Co}, \mathrm{Cu}, \mathrm{Mn}$ and $\mathrm{Ni}$ in surface waters around the British Isles. Cont. Shelf Res. 8: 89-105

McFadzen, I. R. B. (1992). Growth and survival of cryopreserved bivalve larvae along a pollution gradient in the

This article was submitted to the editor
German Bight. Mar. Ecol. Prog. Ser. 91: 215-220

Pattenden, N. J., Cambray, R. S., Playford, K. (1981). Trace and major elements in the sea-surface microlayer Geochim. Cosmochim. Acta 45: 93-100

Stebbing, A. R. D. (1985). Bioassay. In: Bayne, B. L., Brown, D. A., Burns, K., Dixon, D. R., Ivanovici, A., Livingstone, D. R., Lowe, D. M., Moore, M. N., Stebbing, A. R. D., Widdows, J. (eds.) The effects of stress and pollution on marine animals. Praeger, New York, p. 133-137

Stebbing, A. R. D., Dethlefsen, V (1992). Introduction to the Bremerhaven Workshop on Biological Effects of Contaminants. Mar. Ecol. Prog. Ser 91: 1-8

Sünderman, J., Degens, E. T (eds.) (1989). The North Sea. Dungwart, Hamburg

Thain, J. E. (1991). Biological effects of contaminants: oyster (Crassostrea gigas) embryo bioassay. ICES report, Techniques in Marine Environmental Sciences No. 11

Utting, S. D., McFadzen, I. R. B. (1990). Frozen larvae bivalve hatcheries could soon reap benefits. Fish Farmer 6: $45-47$

Utting, S. D., Spencer, B. E. (1991). The hatchery culture of bivalve mollusc larvae and juveniles. MAFF Directorate of Fisheries Research, Lowestoft Laboratory Leaflet No. 68

von Westernhagen, H., Landolt, M., Kocan, R., Furstenberg, G., Janssen, D., Kremling, K. (1987). Toxicity of seasurface microlayer: effects on herring and turbot embryos. Mar environ. Res. 23: 273-290

Woelke, C. E. (1972). Development of a receiving water quality bioassay criterion based on the 48 hour Pacific oyster (Crassostrea gigas) embryo. Wash. Dep. Fish. Tech. Rep. 9: $1-93$

Manuscript first received: February 15, 1993

Revised version accepted: August 25, 1993 